\title{
POULTRY FAECES MANAGEMENT BY BIOCONVERSION TECHNOLOGY WITH MODIFIED GGC 2047 MODEL
}

\author{
S.K. Neupane ${ }^{1}$, Ram K. Sharma ${ }^{2}$, Shiva Shankar Karki ${ }^{3}$ \\ ${ }^{1}$ Department of Civil Engineering, Advanced College of Engineering\& Management, Lalitpur-1, Kathmandu, \\ Nepal \\ ${ }^{2}$ Department of Engineering Science and Humanities, Institute of Engineering, Central Campus, Pulchowk, \\ Tribhuvan University, Nepal \\ ${ }^{3}$ Department of Civil Engineering, Institute of Engineering, Central Campus, Pulchowk, Tribhuvan University \\ Nepal
}

Email Address: shreekrishna.neupane@acem.edu.np

\begin{abstract}
In this report, entitled "Poultry Faeces Management by Bioconversion Technology with Modified GGC 2047 model" focuses on various parameters relating to physico-chemical characteristics of the substrate, fertilizing value of digested poultry waste and potential to create profitability from biogas energy, thus generated and balancing the environmental aspects using poultry waste digestion. Also, biogas may be the tool of energy generation in rural areas while sanitation (waste management) in urban areas of developing countries as Nepal. Biogas production from chicken faeces could be obtained more effectively by feeding around $8.5 \mathrm{~kg}$ per day. It is concluded that digester could be run by around 2.5 quintal chicken faeces per month. Hence those people, who can manage this quantity of waste, can utilize bio-digester without poultry farm.
\end{abstract}

Keywords: GGC, Poultry Faeces, Fertilizing value, Biogas.

\section{Introduction}

Poultry faeces are directly used to fertilize farm for agriculture purpose in developing countries. This is in contrast to industrialized countries where poultry faeces are used only after giving certain degree of treatment as composting. These practices are, however, unaffordable to most urban or rural inhabitants of developing countries.

While substantial progress has been made in the field of solid waste management in developing countries over the past decades, the management and treatment of chicken droppings from poultry farm has not been addressed, either by producers or by any researchers. This is surprising as the absence or insufficiency of adequate poultry faeces management in many cities of developing countries, particularly so in low-income areas, continuously leads to serious health and environmental hazards. Chicken manure is highly sensitive to surface and groundwater as well as results in unaesthetic appearance of the area. Incineration of manure adds to the greenhouse gases in the atmosphere so it is one of the sources of environmental pollution. Currently the fertilizer values of chicken waste are not being fully utilized, resulting in loss of potential nutrients. So, proper management of chicken waste is necessary to achieve the fertilizing value and to reduce the pollution problem. A reason for this backlog in dealing with poultry faeces in urban areas is, among others, the paucity of appropriate managerial and technical measures. 
Disposal of untreated poultry faeces into the farm is one of the major environmental issues in rural area. The use and improper disposal of animal wastes is one of the major sanitation problems in urban and semi-urban areas in developing countries. A number of pathogenic (disease causing) agents are also disseminated through untreated chicken manure and the economic losses accruing from these are enormous. Additionally, the fresh and semi-dried animal droppings sprayed on the farm as fertilizer is a potential health hazard to grazing animals and leaching effect into ground and surface water also poses great danger to humans.

The main focus of this study is to determine the Biogas production with different feeding rates. The specific objectives are; to study and measure the nutrient value (Total Nitrogen, Phosphorus and Potassium) also physical parameters ( $\mathrm{pH}$, Temperature, Moisture Content, Volatile Solids and Total Organic Carbon) of the chicken waste before and after digestion and to evaluate the performance of 4 $\mathrm{m}^{3}$ modified GGC 2047 model, fixed dome bio-digester as approved by BSP Nepal.

\section{Methodology}

Experimental Setup

The study was carried out in three cycles with a time period of 30 days each. Each cycle was conducted continuously and data recorded for gas production was cumulative volume. In all the cycles, layers faeces is only used as feedstock and frequency of feeding was 4 days. In the first cycle (cycle I) dose of feedstock was $30 \mathrm{~kg}$, the second cycle (cycle II) dose of feedstock was $35 \mathrm{~kg}$ and in third cycle (cycle III) feedstock dose was $25 \mathrm{~kg}$ respectively in batch basis. To make slurry, water added to feedstock was 70 liter, 80 liter and 60 liter for first, second and third cycle respectively.

In this study, the included parameters for examinations were; measurement of temperature, $\mathrm{pH}$, moisture content, total volatile solids, total organic carbon, total nitrogen, potassium, and phosphorous. In addition to this, daily biogas production and the cumulative volume was also observed. The conceptual framework of the study in each of the cycle is presented in the Fig1.

Fig1 Conceptual framework of the study 
The methodology used for the study is by experimental study of digestion of poultry waste in $4 \mathrm{~m}^{3}$ modified GGC 2047 model fix dome bio-digester approved by BSP Nepal. The figure of modified digester used for research is given in Fig 2.

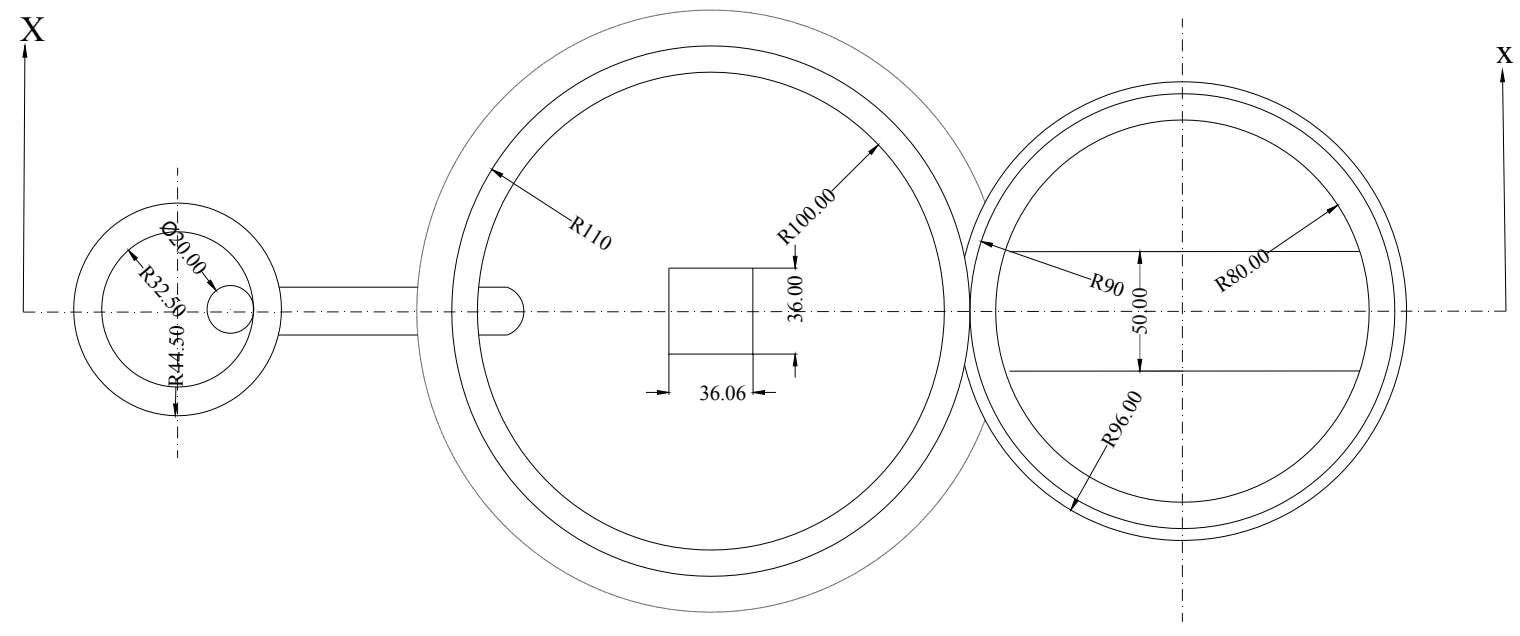

PLAN

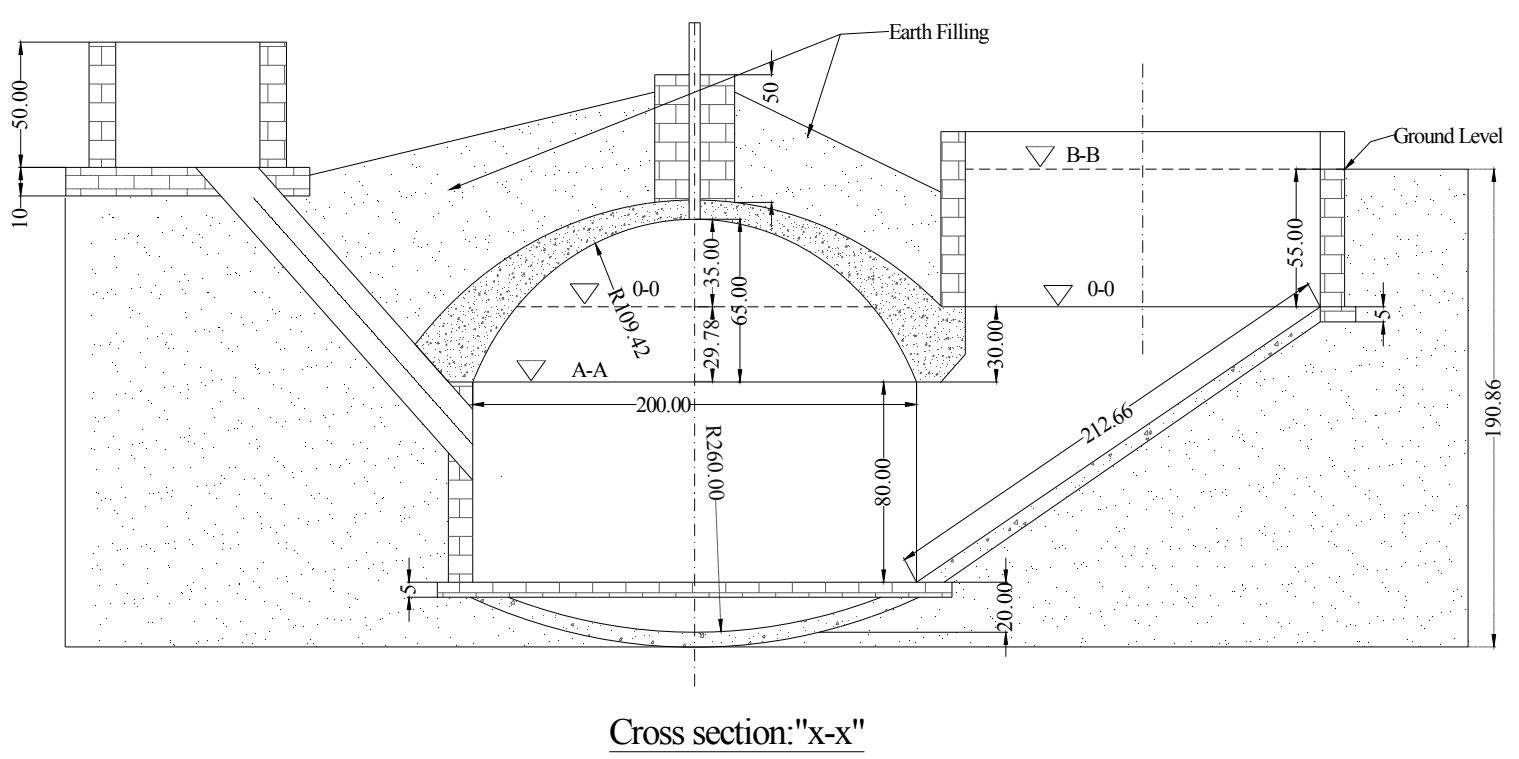

(Note: All dimensions are in centimeter)

Fig 2 Drawing of Modified GGC 2047 model $\left(4 \mathrm{~m}^{3}\right)$ 


\section{Result and Discussion}

In each cycles, the effect on anaerobic digestion of temperature, $\mathrm{pH}$, moisture content, total volatile solids, total organic carbon and total nitrogen, phosphorus and potassium content of influent and effluent were observed and analyzed. In addition to this, the biogas production in cumulative volume and dome pressure was observed and analyzed. The results obtained and their corresponding discussions of observed parameters during the study are presented in this chapter.

\subsection{Variation in Temperature}

Ambient temperature was observed between $25^{\circ} \mathrm{C}$ and $35^{\circ} \mathrm{C}$ where as digester temperature was between $29^{\circ} \mathrm{C}$ and $38^{\circ} \mathrm{C}$ observed in all three cycles as shown in fig 3. Reason of temperature difference is that, during the anaerobic reaction, there will be heat generation; so the reactor temperature is slightly more than ambient.

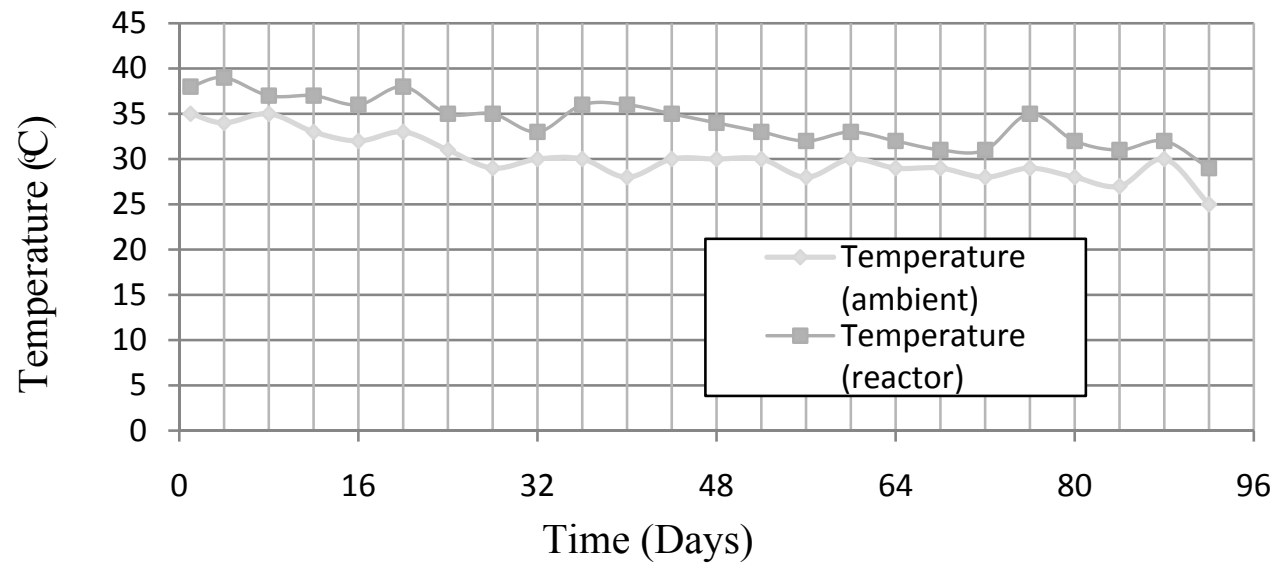

Fig 3 Variations of the temperature in the reactor and ambient

As the minimal average temperature for the methanogenesis process is above 13 degree Celsius. The ambient as well as inside reactor temperature recorded was above 25 degree Celsius. So the temperature recorded here is considered satisfactory for the methanogeneris.

\subsection{Variation in $\mathbf{p H}$}

The variation in $\mathrm{pH}$ of feedstock and sludge in each cycles of each sample are shown in the Fig 4.

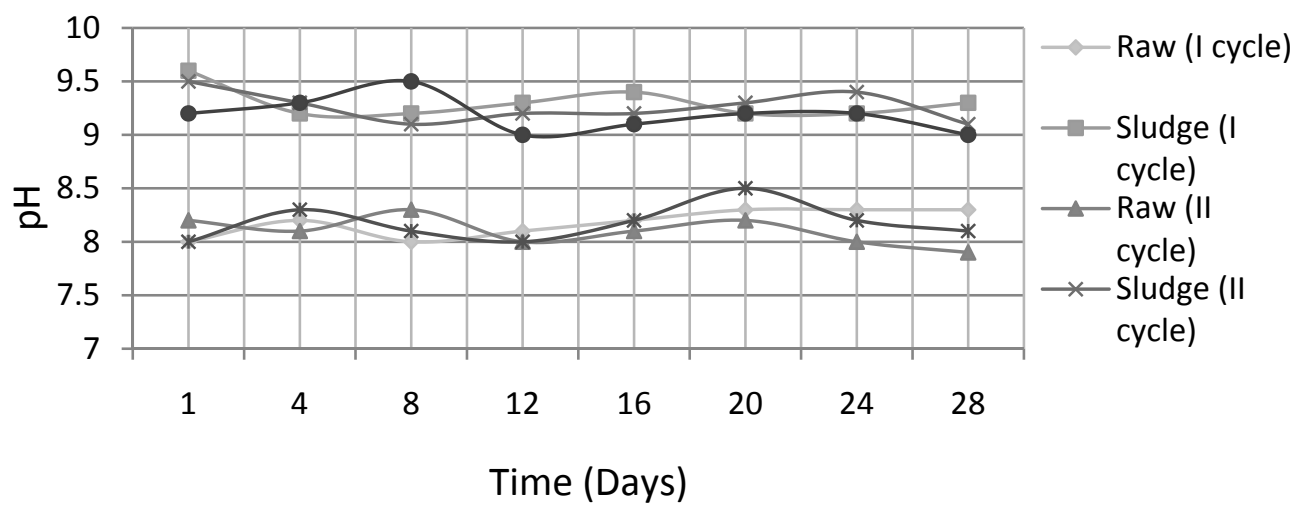

Fig 4 Variations of $\mathrm{pH}$ in the different cycles of each sample

In the cycle I, the $\mathrm{pH}$ of the fresh droppings was found to be 8 and it reached to 9.2 after digestion. Similarly in the rest of two cycles $\mathrm{pH}$ found was like to first cycle. In chapter 2.3.3 it was explained that the optimum biogas production is achieved when the $\mathrm{pH}$ value of input mixture in the digester is 
at 7. Methanogenic bacteria are very sensitive to $\mathrm{pH}$ and do not thrive below a value of 6.5. Here the $\mathrm{pH}$ value obtained was above 6.5 , so the methanogenesis is not presumed to be affected.

\subsection{Variations in Moisture Content}

The variation in moisture content of feedstock and sludge of different cycles of each samples are shown in the Fig 5.

The moisture content variation in all cycle was 75 to 90 percent in sludge where as in raw stage or material 15 to 50 percent. In all cycles the result obtained was quite similar, this is why that, the process is continuous system and feedstock fed was from same poultry farm.

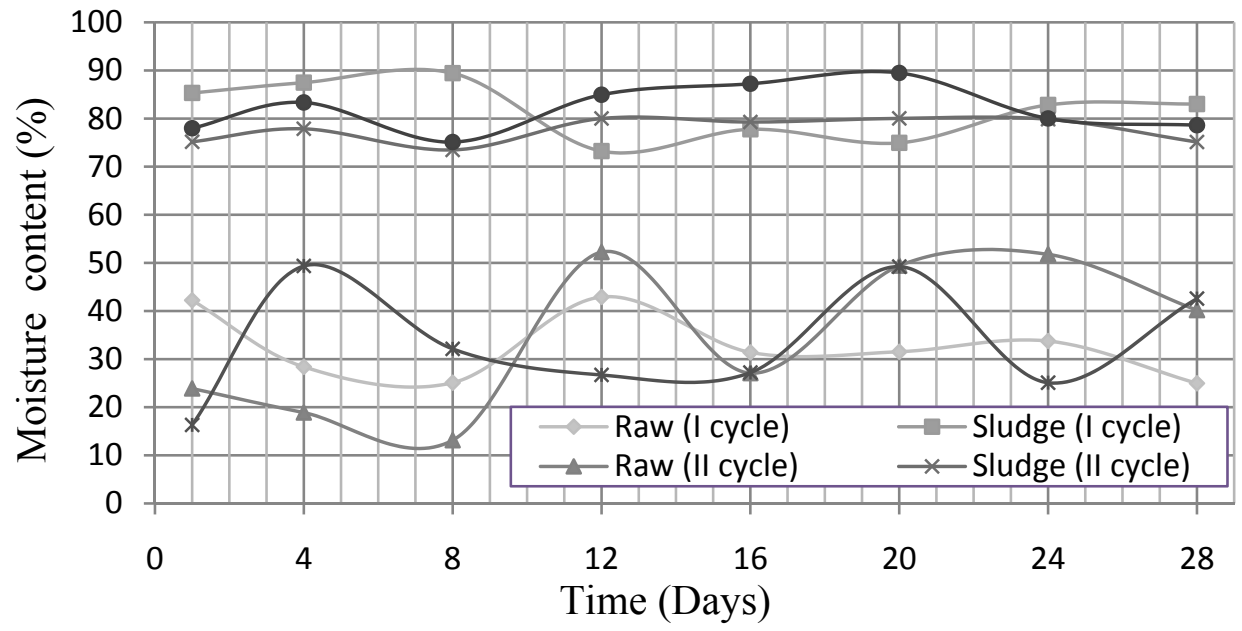

Fig 5 Variations of moisture content in the different cycles of each sample

\subsection{Variations in Volatile Solids}

The variation in the volatile solids in different cycles of each sample has been presented in the Fig 6 .

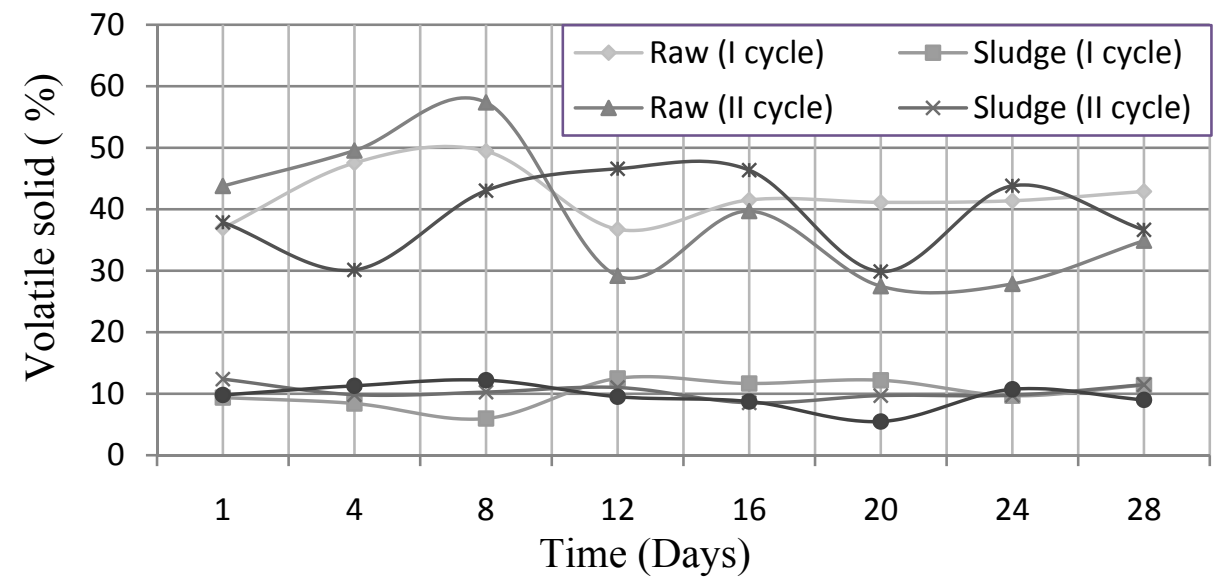

Fig 6 Variations of volatile solids in the different cycles of each sample

The raw chicken droppings containing the volatile solids of 29 to $59 \%$ were found reduced to 8 to $12 \%$ in digested sludge. The volatile solid content of the manure significantly reduced in all the cycles. The reduction of volatile solids in digestion is due to the utilization by microorganisms and for respiration and cell growth. 
The volatile solids representing the organic matter were in decreasing trend throughout the experiment period. The reduction is an indication of stabilization of the fermentation process. The volatile solids in all the cycles were reduced nearly in the similar trend. It represents that the organic matter was steadily decomposed throughout the experimental period in all of the cycles.

\subsection{Variations in Carbon Content}

Total organic carbon was derived from the volatile solid data as per empirical formula by Gottas as stated by Bhandari (2004). It can be related by dividing volatile solids by 1.8 . The change in the total organic carbon in the different cycles of each sample has been presented in the Fig 7 .

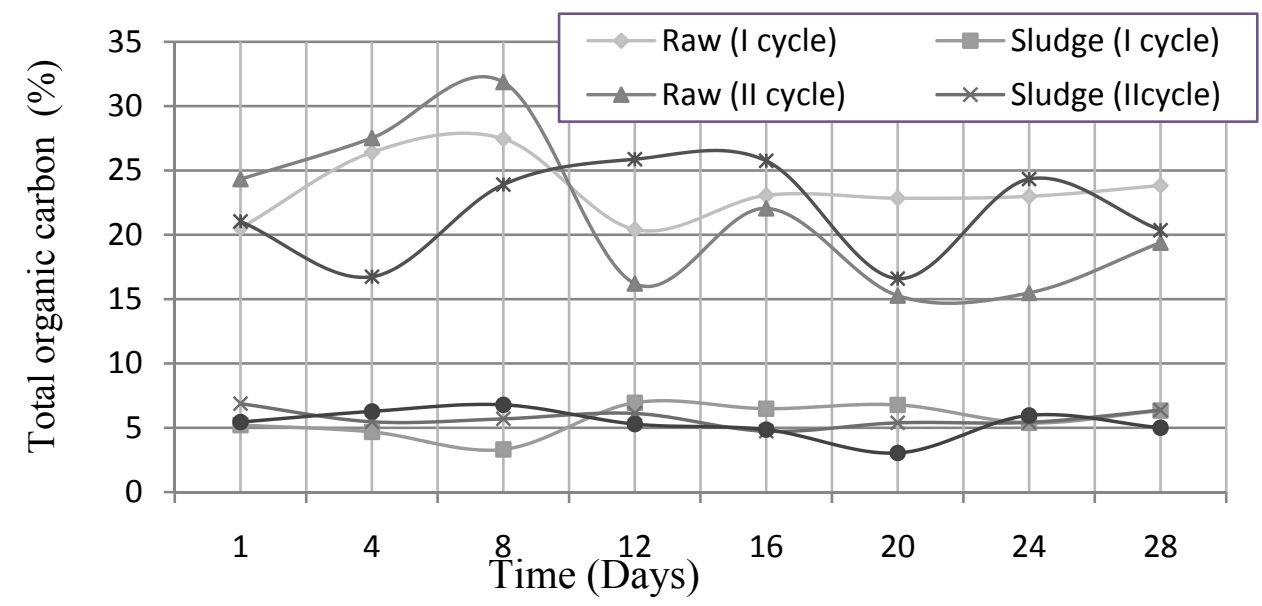

Fig 7 Variations of total organic carbon in the different cycles of each sample

In all cycles, the carbon content range of 15 to $32 \%$ in raw chicken droppings was found reduced to range of 4 to $7 \%$ in digested sludge.

The reduction in carbon content is due to the combustion of carbon substances during the respiration and therefore represents the microbial activity in the anaerobic digestion. The reduction of carbon content was more in third cycle than other cycles. This shows a greater mineralization rate in the anaerobic digestion process due to lowest feeding rate. This indicates that the third is more efficient in the reduction of carbon content.

\subsection{Variation in Nitrogen (N) Content}

The changes in the total nitrogen in the different cycles are presented in the Fig 8.

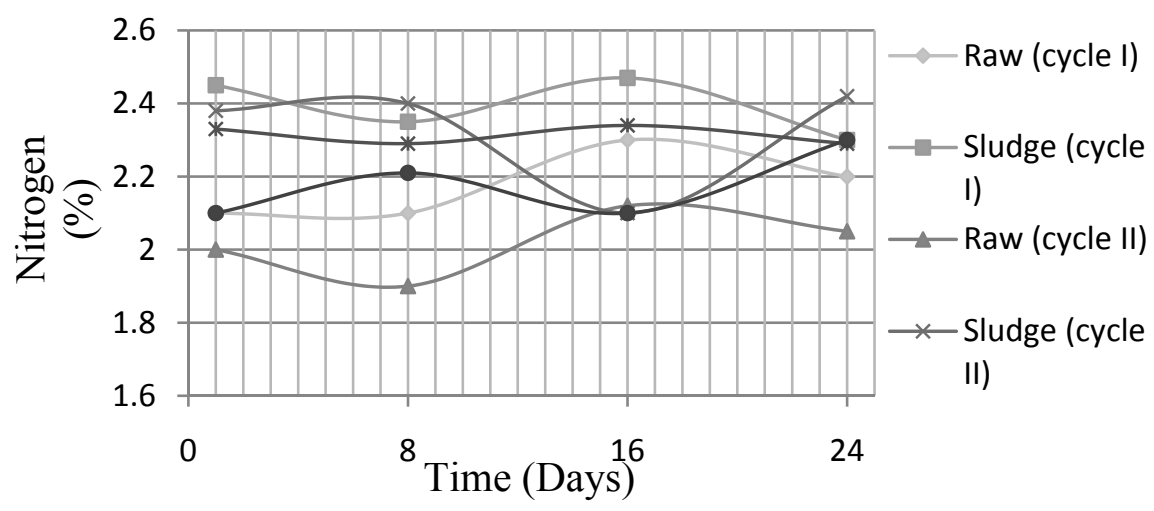

Fig 8 Variations of nitrogen in the different cycles 
The percentage concentration of nitrogen is 2.01 in the raw poultry waste. In the study it was not considered the determination of $\mathrm{NH}_{4}-\mathrm{N}$ salts. So though nitrogen concentration seen to be decreased during fermentation, it is assumed that the total concentration of the ammonia compound is increased (Singh, 2004). Further, once the system becomes stable the methanogens are also capable of adapting to ammonium nitrogen concentrations in the range of 5000 to $7000 \mathrm{mg}$ per liter substrate. The level of nitrogen concentration in this case is increased and the fertilizer value in terms of available nitrogen is also increased in the slurry. Also during the methanogenesis process nitrogen inhibition is presumed to be not occurred here.

\subsection{Variation in Phosphorus $\left(\mathrm{P}_{2} \mathrm{O}_{5}\right)$ Content}

The variation of phosphorus in the different cycles is presented in the Fig 9.



Fig 9 Variations of phosphorus $\left(\mathrm{P}_{2} \mathrm{O}_{5}\right)$ in the different cycles

Phosphorus is $0.66 \%$ at the raw poultry waste and found slightly increased in digested slurry. The concentration of phosphorus has no serious inhibition in the anaerobic digestion. It has retained good level of fertilizer value of digested slurry.

\subsection{Variation in Potassium $\left(\mathrm{K}_{2} \mathrm{O}\right)$ Content}

The variation of potassium in the different cycles is presented in the Fig 10.

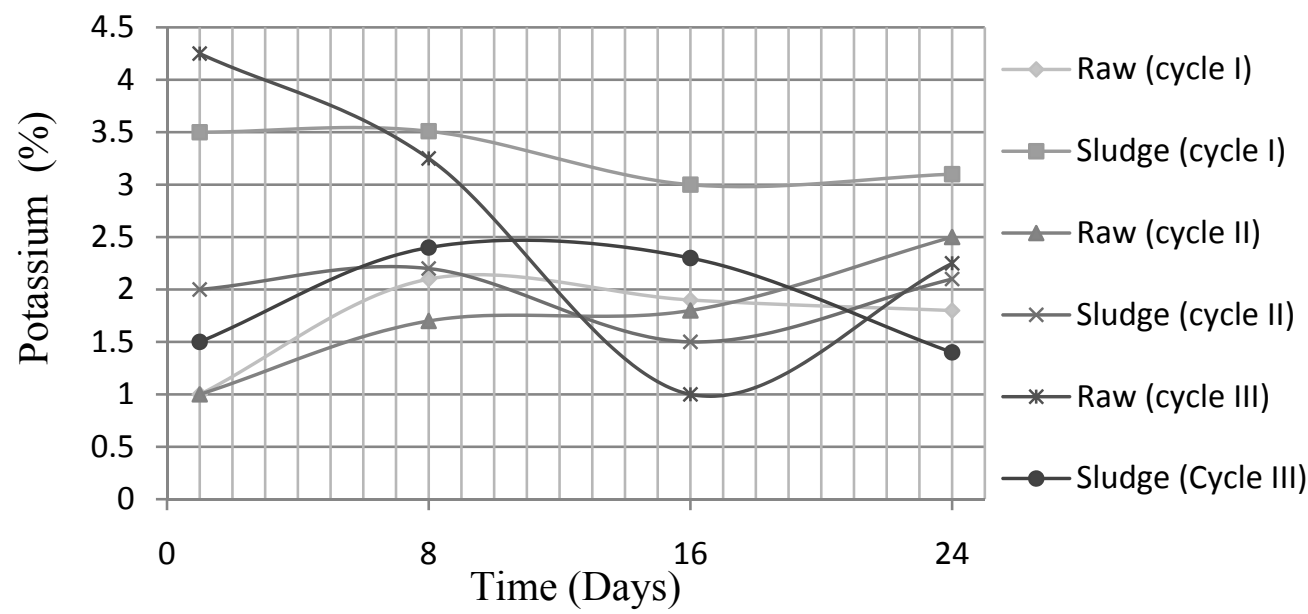

Fig 10 Variations of potassium $\left(\mathrm{K}_{2} \mathrm{O}\right)$ in the different cycles 
The initial potassium content in the raw chicken droppings was $1.01 \%$ in cycle I and in the similar trend of rest two cycles. The potassium content of the slurry has no serious affect on the inhibition of methanogenic bacteria. However it is considered to be beneficial to the fertilizer value of the slurry.

It has been observed that all the cycles are good in terms of conservation of nutrient nitrogen, phosphorus and potassium. Overall nutrient conversion is higher in anaerobic digestion. The changes in the nutrient values during the different cycles were variable and a distinct pattern was not observed but the pattern followed is in increasing order.

\subsection{Variations in Carbon to Nitrogen Ratio (C/N)}

The change in the $\mathrm{C} / \mathrm{N}$ ratio in the different cycles of eight days sample has been presented in the Fig 11.

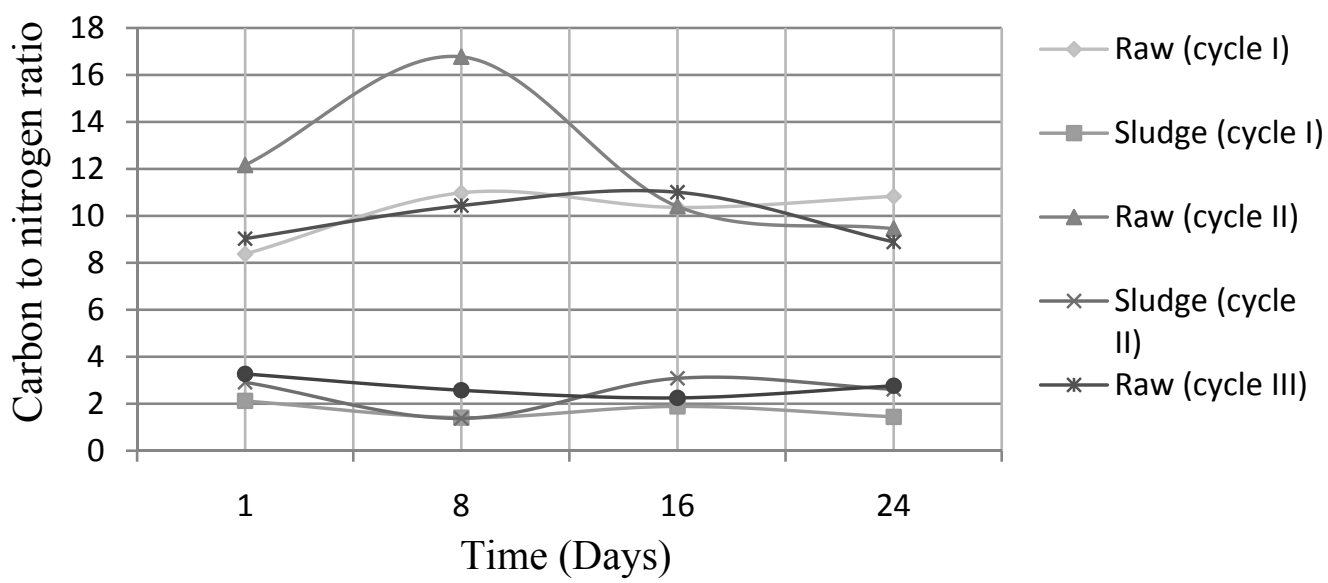

Fig 11 Variations of carbon to nitrogen ratio $(\mathrm{C} / \mathrm{N})$ in the different cycles

The initial $\mathrm{C} / \mathrm{N}$ ratio in the raw chicken dropping was 10 in cycle I and its value were reduced after digestion to 3 . Rest of cycles value observed was also in the similar trend.

If $\mathrm{C} / \mathrm{N}$ ratio is very high, the nitrogen will be consumed rapidly by methanogens for meeting their protein requirements and will no longer react on the left over carbon content of the material. As result, gas production will be low. On the other hand, if the $\mathrm{C} / \mathrm{N}$ ratio is very low; nitrogen will be librated and accumulated in the form of ammonia. Ammonia will increase the $\mathrm{pH}$ value of the content in the digester. At $\mathrm{pH}$ higher than 6.5 , it will start showing toxic effect on methanogen population (FAO/CMS, 1996).

All the systems showed a decreasing trend in the $\mathrm{C} / \mathrm{N}$ ratio as reported by Bansal and Kapoor (1999). The lowering of $\mathrm{C} / \mathrm{N}$ ratio is due to the combustion of carbon substances during respiration. The value of $\mathrm{C} / \mathrm{N}$ ratio is one of the most widely used indices do determine the slurry digestion.

\subsection{Variations in Biogas Production}

The gas produced is recorded in the flow meter. The gas produced which is measured in flow meter has been presented in the Fig 12 . 


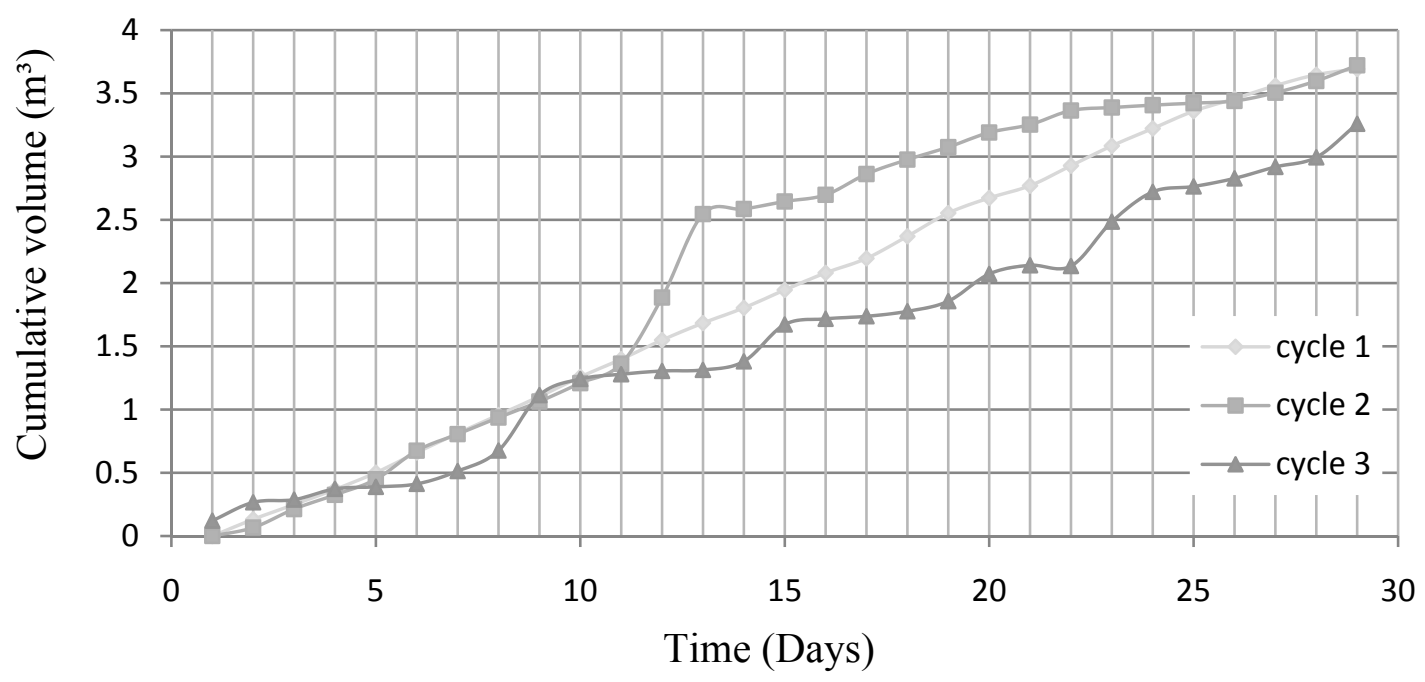

Fig 12 Variations of production of biogas in the different cycles

Higher biogas production was observed in second cycle than of other first and third cycle due to the higher feeding of poultry waste. By the observation it is known that biogas production from chicken droppings could be obtained more efficient by feeding around $8.5 \mathrm{~kg}$ per day. In second cycle there is more volatile solid destruction then other two cycles that is the reason of more gas generation. The biogas produced in the second cycle has greater volume among all other cycles due to higher feeding rate.

\section{Conclusion}

From the experiment, it was concluded that the biogas generation from chicken manure could be carried out successfully in the layers faeces. Based on the results obtained from the experiment and analysis of the results, the following conclusions were drawn;

1. The temperature requirement for bacteriological methane production was easily obtained in the research period. The temperature obtained in fermentation chamber was about $4^{\circ} \mathrm{C}$ above from ambient. It is suggested that the gas production can be increased in cold season by providing proper insulation of digester.

2. The methane producing bacteria thrive under neutral to slightly alkaline conditions. It was observed that the $\mathrm{pH}$ of raw chicken droppings remain in alkaline range of 8 to 8.5.

3. The moisture content obtained in chicken droppings was 15 to $50 \%$, so that water added to prepare slurry required was relatively high to other animals dung like cow/buffalo and also the reason is that of more water requirement as higher ambient temperature observed was around $35^{\circ} \mathrm{C}$. The effluent or digested sludge or slurry has moisture content range of 75 to $90 \%$.

4. The raw chicken droppings containing the volatile solids of 29 to $59 \%$ were found reduced to 8 to $12 \%$ in digested sludge. The volatile solid content of the manure significantly reduced in all the cycles. The reduction of volatile solids in digestion is due to the utilization by microorganisms and for respiration and cell growth.

5. The carbon content range of 15 to $32 \%$ in raw chicken droppings was found reduced to range of 4 to $7 \%$ in digested sludge. The reduction in carbon content is due to the combustion of carbon substances during the respiration and therefore represents the microbial activity in the anaerobic digestion.

6. It has been observed that all the cycles are good in terms of conservation of nutrients nitrogen, phosphorus and potassium. Overall nutrient conversion is higher in anaerobic digestion. The 
changes in the nutrient values during the different cycles were variable and a distinct pattern was not observed but the pattern followed is in increasing order.

7. The initial $\mathrm{C} / \mathrm{N}$ ratio in the raw chicken dropping was 10 in cycle $\mathrm{I}$ and its value were reduced after digestion was 3. Rest of cycle's value observed is that of similar trend. For metabolic activity, the $\mathrm{C} / \mathrm{N}$ ratio of methanogenic bacteria is found to be optimized at approximately 8 to 10 , here also the observed ratio remains to this range. If $\mathrm{C} / \mathrm{N}$ ratio is very high, the nitrogen will be consumed rapidly by methanogens for meeting their protein requirements and will no longer react on the left over carbon content of the material. As result, gas production will be low.

8. It is recommended that biogas production from chicken droppings could be obtained more effectively by feeding around $8.5 \mathrm{~kg}$ per day. During the study average burning period of stove or consumption of produced gas was 2.5 hours. It is concluded that digester could be run by around 2.5 quintal chicken droppings per month hence those family who can manage this quantity waste; they can construct bio-digester without having their own poultry farm.

\section{Acknowledgement}

This work was supported by the BSP Nepal by providing instrument flow meter, pressure gauge and other accessories for the analysis. We would like to extend our heartfelt gratitude and sincere appreciation to Professor Dr. Bhagwan Ratna Kansakar for his encouragement and valuable suggestions till this final stage of the study.

\section{References}

1. S. Bansal and K. K. Kapoor, "Vermicomposting of Crop Residue and Cattle Dung with Eisenia Foetida". Bioresource Technology, 73: 95-98, 1999.

2. H. S. Bhandari, "Survival Growth and Reproduction of Eisenia Fetida During degradation of Dried Human Feces". MSc. Thesis No. 058/MSE/302, IOE, Pulchowk-Nepal, 2004.

3. CAMMG, "Canada Animal Manure Management Guide”, Agriculture Canada. Ottawa,1979

4. D. R. Cullimore, A. Maule and N. Mansuy, "Ambient Temperature Methanogenesis from Pig Manure Waste Lagoons; Thermal Gradient Incubator Stuidies”, Agricultural Wastes, 1985.

5. FAO/CMS, Food and Agriculture Organization of The United Nations, Support for Development of National Biogas Programme (FAO/TCP/NEP/4451-T), "Biogas Technology: A Training Manual for Extension”, Consolidated Management Services Nepal (P) Ltd, 1996.

6. ISAT/GTZ, "Biogas Digest Volume I. Biogas Basics", Information and Advisory Service on Appropriate Technology (ISAT/GTZ), 1999.

7. A. B. Karki and Sahayogi Dixit, N. Prakasha, "Biogas Field book”, 1984.

8. A. B. Karki, "Training Manual in Biogas Technology for the Trainers of Jonior Bigas Technology”, Biogas Support Programme, 2000.

9. L. Ke-Xin, and L. Nian-Guo, "Fermentation technology for rural digesters in China", Proceeding of Bioenergy’80, Bio-Energy Council, New York, 1980.

10. I.W. Kroodsma, Treatment of livestock manure: Air draying and composting poultry manure, In: "Odour prevention and Control of Organic Sludge and Livestock Farming", The Netherlands, pp. 166-174, 1986. 
11. B. Lagrange, Biomethane 2: "Principle Techniques Utilization", EDISUD. La Calade, 13100 Aix-en-Provence, France, 1979.

12. T. H. Lane, and T. E. Bates, "Samplingand Chemical Analysis of Manure", In: The Manure Management Handbook, Ont, Soil and Crop Imp. Ass.. Ont. Min. of Agriculture and Food, Ont, Agriculture Collage, Canada, 1982.

13. M. S. Lund, S. S. Andersen M. Torry-Smith, "Building of a Flexibility Bag Biogas Digester in Tanzania”, Student Report, Technical University of Denmark. Copenhagen, 1996.

14. Müller Christian, May, "Anaerobic Digestion of Biodegradable Solid Waste in Low- and Middle-Income Countries”, Dübendorf, 2007.

15. A. Mariakulandai, and T. S. Manickam, "Chemistry of Fertilizers and Manures", Aaia Publication House, New Yourk, U.S.A.,1975.

16. I. Narisara, T. Supparak and M. Vissanu, "Biogas Production from Co-Digestion of Animal wastes", The Proceeding of the $9^{\text {th }}$ APCChE Congress abd CHEMECA 2002, Christchurch, New Zealand, 2002,

17. NBPG \& CADEC, “Biogas Sector in Nepal” supported by BSP -Nepal, 2007.

18. L. M. Safely, “Operating a full-scale poultry manure anaerobic digester”. Biological Wastes, 1987.

19. M. A. Sathianahan, "Biogas Achievements and challenges", Association of Voluntary Agencies of Rural Development, New Dehli, India,1975.

20. R. Singh, "Production of Biogas from Poultry Waste in Kathmandu”, MSREE, IOE PulchowkNepal, 2004.

21. SNV/BSP, “Abstracts of Biogas Related Publication” (1992-2002)

22. Standard Methods, "Standard Methods for the Examination of Water and Wastewater". American Public Health Association, 1989.

23. J. G. Zeikus, and M. R.Winfrey, "Temperature Limitation of Methangenesi in Aquatic Systems", Applied and Environmental Microbiology, 1976. 